\title{
P290: Infection control in dialysis unit-difficult but not impossible
}

\author{
M Sri Ratnamani, R Rao, ICT \\ From 2nd International Conference on Prevention and Infection Control (ICPIC 2013) \\ Geneva, Switzerland. 25-28 June 2013
}

\section{Introduction}

Infection control in the dialysis unit has its own concerns. These patients are prone to Hospital acquired infections due their lowered immune status, repeated hospital admissions and multiple lines. Infection complications include bacterial and blood borne pathogens either by water, equipment or environment. We implemented a few basic practices to control the infections in our Dialysis unit.

\section{Objectives}

Implementation of Infection control practices in Dialysis unit.

\section{Methods}

First the parameters which needed to be monitored in the Dialysis unit was decided. It included both inpatients and outpatients.

\section{Quality indicators}

1) Number of patients undergoing dialysis developing CLBSI 2) Serconversion in these patients. 3) Surveillance of water quality(RO water\& Dialysate).

\section{Implemented practices}

a) SUD reuse policy. b) Appropriate handling of dirty hemodialysers. c) Proper disinfection of dialysis machines (internal \& External). d) Proper disinfectation of vascular access prior to cannulation. e) Unannounced audits and corrective actions. f) Good \& effective Post exposure prophylaxis for staff. g) Dedicated equipment for HBS Ag, HCV positive patients. [1,2].

\section{Results}

By regular monitoring of these parameters we been able to control infections in dialysis patients. This month the dialysis unit got best unit award as a rolling trophy.

\section{Conclusion}

Dialysis units need a stringent Infection control practices. Lack of time and will to implement need to be addressed. Educating the staff and constant motivation helps in achieving this goal. A good staff to patient ratio should also be maintained.

\section{Competing interests}

None declared.

Published: 20 June 2013

\section{References}

1. Dix Kathy: Infection Control in the Dialysis Setting., Posted in Articles, Infections, Healthcare-Acquired Infections (HAIS), Hepatitis, Infectious

Diseases, Viruses, Centers For Disease Control And Prevention (CDC), Public Health, Guidelines \& Regulations, Research \& Studies, Patient/Worker Safety, Surveillance \& Epidemiology.

2. CDC: "Recommended set of interventions to prevent blood stream infections (BSI) in hemodialysis patient"s..

\section{doi:10.1186/2047-2994-2-S1-P290}

Cite this article as: Sri Ratnamani et al:: P290: Infection control in dialysis unit-difficult but not impossible. Antimicrobial Resistance and Infection Control 2013 2(Suppl 1):P290.

Microbiology, Apollo hospitals, Hyderabad, India

(c) 2013 Sri Ratnamani et al; licensee BioMed Central Ltd. This is an Open Access article distributed under the terms of the Creative 